\title{
Construction supervision during capital construction, reconstruction and re-profiling
}

\author{
Dmitriy Topchiy ${ }^{1}$, Alexey Yurgaytis ${ }^{1, *}$, Evgeniy Babushkin ${ }^{1}$, and Diana Zueva ${ }^{1}$ \\ ${ }^{1}$ Moscow State University of Civil Engineering, Yaroslavskoe shosse, 26, Moscow, 129337, Russia
}

\begin{abstract}
This article raises problems related to the shortcomings in the existing field of construction supervision and the relationship between participants in the construction process. An article dedicated to the implementation of comprehensive and comprehensive construction supervision at capital construction sites, bringing the construction supervision system to a standard that minimized the customer's risks and minimized the number of errors in the construction industry. The aim of the article is to find solutions and ways to resolve problems, because of which there are many qualities, as well as the timing of projects for investment and construction activities. On the basis of a statistical analysis of the current situation and world experience, the main proposals for the improvement of construction supervision systems are presented.
\end{abstract}

\section{Introduction}

In modern realities, construction is a complex process that requires close monitoring by all participants and the state. Construction supervision throughout the construction, operation of the completed facility, as well as reconstruction and overhaul is necessary to optimize the quality of finished construction products, that is, capital construction facilities. The system of control and supervision over the implementation of the capital construction facility at all stages is presented in table 1 . The most significant area of work in this matter today is the development of standards for conducting construction supervision within the amended regulatory framework. The study of the existing procedure for conducting construction supervision and identifying directions for improving this system is the main goal of this article.

\section{Methods}

The main method of conducting the study was to analyze the existing structure of construction supervision. The study of the existing regulatory framework and the identification of shortcomings in it regarding the lack of complex and comprehensive construction control, the analysis of international experience in construction supervision became the basis for developing a number of proposals for improving this system.

\footnotetext{
*Corresponding author: evgenii.babushkin@gmail.com
} 
Table 1. Control and supervisory system at the stages of implementation of the capital construction object.

\begin{tabular}{|c|c|c|c|c|}
\hline $\begin{array}{l}\text { Stages of } \\
\text { implementation } \\
\text { of the capital } \\
\text { construction } \\
\text { object }\end{array}$ & Pre-design stage & Project stage & Stage of the project & $\begin{array}{l}\text { Stage of operation } \\
\text { of finished } \\
\text { construction } \\
\text { products }\end{array}$ \\
\hline $\begin{array}{l}\text { Content of the } \\
\text { implementation } \\
\text { stage }\end{array}$ & $\begin{array}{l}\text { - the idea of a } \\
\text { future project; } \\
\text { - technical } \\
\text { conditions; } \\
\text { - feasibility study; } \\
\text { - surveys; } \\
\text { - source permitting } \\
\text { documentation }\end{array}$ & $\begin{array}{l}\text { - development } \\
\text { of project } \\
\text { documentation } \\
\text { - examination } \\
\text { of project } \\
\text { documentation }\end{array}$ & $\begin{array}{l}\text { - development of working } \\
\text { documentation; } \\
\text { - formation of a package of } \\
\text { executive documentation }\end{array}$ & $\begin{array}{l}\text { - technical operation } \\
\text { of the capital } \\
\text { construction facility } \\
\text { during the design } \\
\text { service life }\end{array}$ \\
\hline $\begin{array}{l}\text { Control } \\
\text { activities at this } \\
\text { stage }\end{array}$ & $\begin{array}{l}\text { - external control } \\
\text { by the technical } \\
\text { customer }\end{array}$ & $\begin{array}{l}\text { - external } \\
\text { control by the } \\
\text { technical } \\
\text { customer; } \\
\text { - internal } \\
\text { control of the } \\
\text { project } \\
\text { organization; } \\
\text { - state / non- } \\
\text { state expertise }\end{array}$ & $\begin{array}{l}\text { - control by the technical } \\
\text { customer (including } \\
\text { verification laboratory } \\
\text { control); } \\
\text { - construction supervision } \\
\text { of the contractor; } \\
\text { - design supervision of the } \\
\text { project organization; } \\
\text { - non-state construction } \\
\text { supervision }\end{array}$ & $\begin{array}{l}\text { - control of the } \\
\text { management } \\
\text { company }\end{array}$ \\
\hline $\begin{array}{l}\text { Results at this } \\
\text { stage }\end{array}$ & $\begin{array}{l}\text { - the basis for the } \\
\text { design; } \\
\text { - formation of a } \\
\text { package of initial } \\
\text { permissive } \\
\text { documentation }\end{array}$ & $\begin{array}{l}\text { - a positive } \\
\text { conclusion on } \\
\text { the } \\
\text { examination } \\
\text { of project } \\
\text { documentation }\end{array}$ & $\begin{array}{l}\text { - construction of object of } \\
\text { capital construction }\end{array}$ & $\begin{array}{l}\text { - proper operation } \\
\text { and functioning of } \\
\text { the structures, } \\
\text { systems and } \\
\text { networks of the } \\
\text { object }\end{array}$ \\
\hline $\begin{array}{l}\text { Risks at this } \\
\text { stage }\end{array}$ & $\begin{array}{l}\text { - increase the } \\
\text { duration of the pre- } \\
\text { project stage }\end{array}$ & $\begin{array}{l}\text { - latent design } \\
\text { errors }\end{array}$ & - errors during the work & $\begin{array}{l}\text { - violation of safe } \\
\text { and reliable } \\
\text { operation }\end{array}$ \\
\hline
\end{tabular}

\section{Literature review}

According to the Urban Planning Code of the Russian Federation, the following three types of activities for capital construction projects are distinguished: construction, reconstruction (including conversion) and overhaul. For this purpose, at all stages of planning and production of these types of activities, construction supervision is carried out, which is a check of compliance of the executed work with design decisions, technical regulations and requirements for construction and reconstruction.

Construction supervision based on the requirements of existing regulatory documents in construction. The main tasks, functions, rights and responsibilities of construction supervision are regulated by:

- "Urban Development Code of the Russian Federation" of 29.12.2004 N 190-FZ, Article 53 ;

- Decree of the Government of the Russian Federation of June 21, 2010 No. 468 "On the procedure for conducting construction supervision in the implementation of construction, reconstruction and overhaul of capital construction projects" (together with the "Regulations for construction supervision in the construction, reconstruction and overhaul of capital construction projects");

-"SP 48.13330.2011. Set of rules. Organization of construction. Updated version SNiP 12-01-2004", section 7;

- Order of the Ministry of Regional Development of the Russian Federation of 30.12.2009 $\mathrm{N} 624$ "On approval of the List of types of works on engineering surveys, preparation of 
project documentation, construction, reconstruction, overhaul of capital construction projects that affect the safety of capital construction projects";

- Order of the State Construction Committee of the Russian Federation of 25.02.1999 N 39 "On improving the skills of specialists who exercise control over the quality of construction of facilities";

- other national standards (GOST, SP, TR).

For today in Russia there are following stages of the construction supervision:

1) visual and instrumental control;

2) laboratory testing;

3) geodetic control;

4) audit of the documentation of the stage "RD";

5) checking of the executive documentation;

6) verification of organizational and technological documentation.

Table 2. Some typical consequences revealed during the verification control by the customer.

\begin{tabular}{|c|l|l|}
\hline No & \multicolumn{1}{|c|}{$\begin{array}{c}\text { Stages of the construction } \\
\text { supervision }\end{array}$} & \multicolumn{1}{|c|}{$\begin{array}{c}\text { Some typical consequences revealed during the } \\
\text { verification control by the customer }\end{array}$} \\
\hline 1. & Visual and instrumental control & cracks in monolithic reinforced concrete structures \\
\hline 2. & Laboratory testing & discrepancy of the actual concrete strength class \\
\hline 3. & Geodetic control & over-standard deflections of floor slabs \\
\hline 4. & $\begin{array}{l}\text { Audit of the documentation of the } \\
\text { stage "RD"; }\end{array}$ & $\begin{array}{l}\text { the use of materials and equipment inappropriate to } \\
\text { stage «P» }\end{array}$ \\
\hline 5. & $\begin{array}{l}\text { Checking of the executive } \\
\text { documentation }\end{array}$ & $\begin{array}{l}\text { absence of separate certificates of survey of } \\
\text { responsible constructions }\end{array}$ \\
\hline 6. & $\begin{array}{l}\text { Verification of organizational and } \\
\text { technological documentation }\end{array}$ & $\begin{array}{l}\text { identification of the application in the project of the } \\
\text { production of demolition work of the shock } \\
\text { demolition method }\end{array}$ \\
\hline
\end{tabular}

Construction supervision can be carried out by all construction participants and the state:

1) the person in charge of the construction (General Contractor). Conducts operational (current control) at the construction site. The tasks of the contractor include: checking incoming materials and equipment, monitoring the storage and processing of material resources, checking the correctness of the performance of technological processes. These tasks the contractor decides independently (ie, performs self-monitoring). The tasks associated with the acceptance and delivery activities, he decides in conjunction with the customer. Such tasks include: survey of hidden works, acceptance of certain types of work and construction stages, verification of compliance with the completed construction of the facility;

2) technical customer. Construction supervion by the technical customer includes checking the deadlines and volumes of work, checking the contractor's maintenance of control documentation, estimating the scope and timing of the verification of technological processes by the contractor, accepting certain types of work and construction phases, accepting hidden works, checking the compliance of project and regulatory documents completed construction facility. The control of a technical customer can be permanent (the daily presence of a customer representative at the construction site) or periodic;

3) general designer. Carries out the author's supervision of the connection of construction. The presence of such control depends on the desire of the customer (or developer). The tasks of the designer include: assessment of the object's compliance with design solutions, control of compliance with production technology, control of the use of materials and structures, project facilities. The designer performs control on behalf of the customer or developer;

4) supervisory organization. This is an external organization that specializes in construction supervison. It acts only on behalf of the customer or the builder. It is attracted 
in case the developer (customer) can not solve the tasks of construction supervision assigned to him at the proper professional level;

5) state. Conducted by government agencies of executive power (construction supervision services).

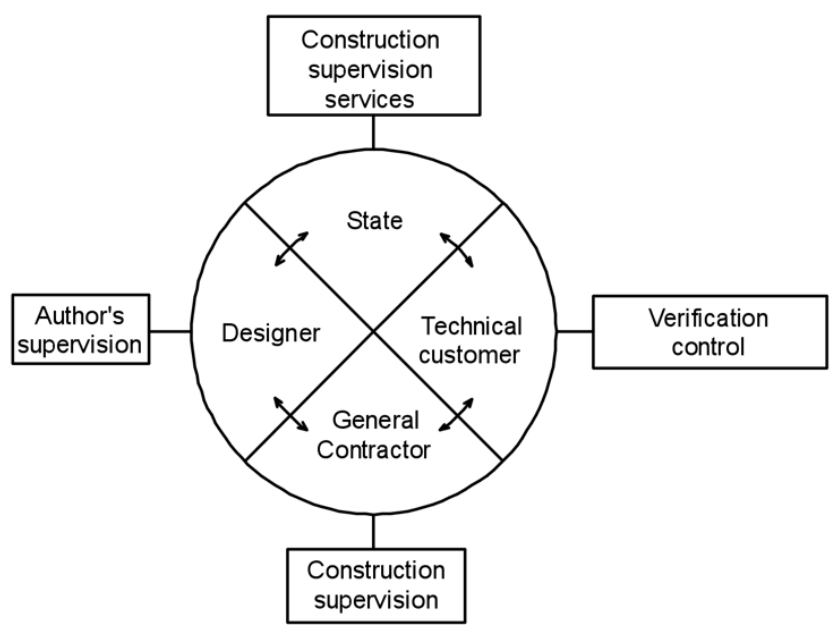

Fig. 1. The main participants of construction supervision.

Control by the customer is not standardized and in fact is not limited to any framework. This is confirmed by the fact that in the framework of this study, it was not possible to find large objects for statistical research, at which the customer did not call for a second testing laboratory to perform contractor control (Table 3). This is due to the fact that in this way the customer tries to minimize risks when accepting substandard construction products from the General Contractor. It identifies inconsistencies in actually executed works and executive documentation with the working documentation developed before delivery to the site.

Table 3. Comparison of the number of contractor's tests and verification control of the customer.

\begin{tabular}{|c|c|c|}
\hline No & $\begin{array}{c}\text { Number of tests performed in the } \\
\text { laboratory of the general contractor }\end{array}$ & $\begin{array}{c}\text { Number of repeated tests of } \\
\text { verification control by the customer }\end{array}$ \\
\hline 1. & $2-5$ & 2 \\
\hline 2. & $6-10$ & 3 \\
\hline 3. & $11-20$ & 5 \\
\hline 4. & $21-30$ & 8 \\
\hline 5. & $31-50$ & 12 \\
\hline
\end{tabular}

It is also worth noting that there are not so many mandatory requirements for those exercising construction supervision. These include certification and accreditation of laboratories. The provision of documents certifying qualifications on a voluntary basis has a much larger scale and is often caused by the organization's initiative. Separately, for the production of construction supervision at the facilities of the oil and gas industry, as well as facilities for the use of atomic energy, it is necessary to obtain a certificate of admission to work on the implementation of construction control during construction, reconstruction and major repairs. Another mandatory item for construction supervision was environmental control, carried out by an environmental laboratory that received certification and accreditation. Environmental monitoring includes measurements of noise, vibration, water, air and soil, and so on. 
Table 4. List of documents of mandatory and voluntary certification for construction control.

\begin{tabular}{|c|c|c|c|}
\hline $\mathrm{N}$ & $\begin{array}{c}\text { Stages of the construction } \\
\text { supervision }\end{array}$ & Mandatory document & $\begin{array}{c}\text { Voluntary } \\
\text { confirmation of } \\
\text { qualifications }\end{array}$ \\
\hline 1. & $\begin{array}{c}\text { Visual and instrumental control } \\
\text { (besides the visual and } \\
\text { measuring inspection of welds) }\end{array}$ & $\begin{array}{c}\text { - } \\
\text { (in some cases, the SRO for } \\
\text { inspection of buildings and } \\
\text { strures; for visual and measuring } \\
\text { inspection of welds - license) }\end{array}$ & $\begin{array}{c}\text { Attestation, } \\
\text { refresher } \\
\text { courses }\end{array}$ \\
\hline 2. & Laboratory testing & Certification & Accreditation \\
\hline 3. & Geodetic control & SRO & Certification \\
\hline 4. & $\begin{array}{c}\text { Audit of the documentation of } \\
\text { the stage "RD"; }\end{array}$ & SRO & $\begin{array}{c}\text { Attestation, } \\
\text { refresher } \\
\text { courses }\end{array}$ \\
\hline 5. & $\begin{array}{c}\text { Checking of the executive } \\
\text { documentation }\end{array}$ & - & Licensing \\
\hline 6. & $\begin{array}{c}\text { Verification of organizational } \\
\text { and technological } \\
\text { documentation }\end{array}$ & - & - \\
\hline
\end{tabular}

For inspection of buildings and structures and issuing decisions on the construction, operation, demolition of buildings with a high level of responsibility, an SRO is required for the inspection of buildings and structures.

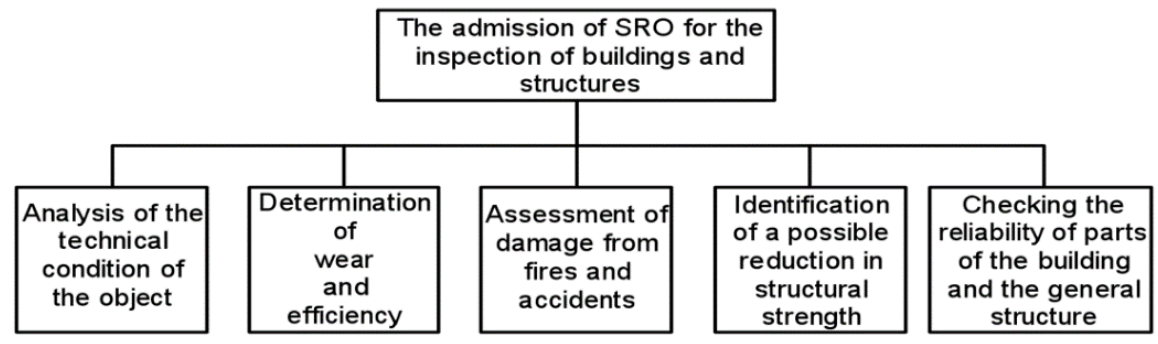

Fig. 2. List of works available with SRO for inspection of buildings and structures.

Within the framework of the implementation of control and supervisory functions in the construction industry in different countries at different stages of design, construction and operation of construction objects, construction supervision is carried outs. A significant part of them is implemented with the involvement of external experts and expert organizations. In the United States, the project of each construction site undergoes mandatory state expertise and, following its results, the construction organization receives permission for the construction of the facility. In Germany (as in most European countries), state expertise of the project is also a mandatory requirement. Expertise is based on the principles of independence of experts, their high qualifications, validity of conclusions and responsibility for the result. Under the terms of the legislation, highly qualified experts included in the register of state experts may be recruited as external experts to conduct state expertise. Inclusion in the register of state experts is carried out on a competitive basis, taking into account the principles of independence of experts, their qualifications and work experience. When included in the roster, experts are sworn in. Thus, experts and expert organizations are mainly involved in the market in the United States. Their selection is made according to the 
qualification criteria, without additional mechanisms of certification or accreditation. In Germany, the involvement of experts in this field is carried out both on the basis of qualifications and using pre-selection mechanisms. Thus, in the field of control and supervision in construction in Germany, experts are involved with the use of hybrid and market mechanisms.

The most famous international organization providing construction consulting services is FIDIC, the international federation of consulting engineers.

Based on the analysis of international experience and parallels with the situation in our country, it is possible to propose a solution for comprehensive and comprehensive construction control, which can be represented as an integral matrix of construction supervision.

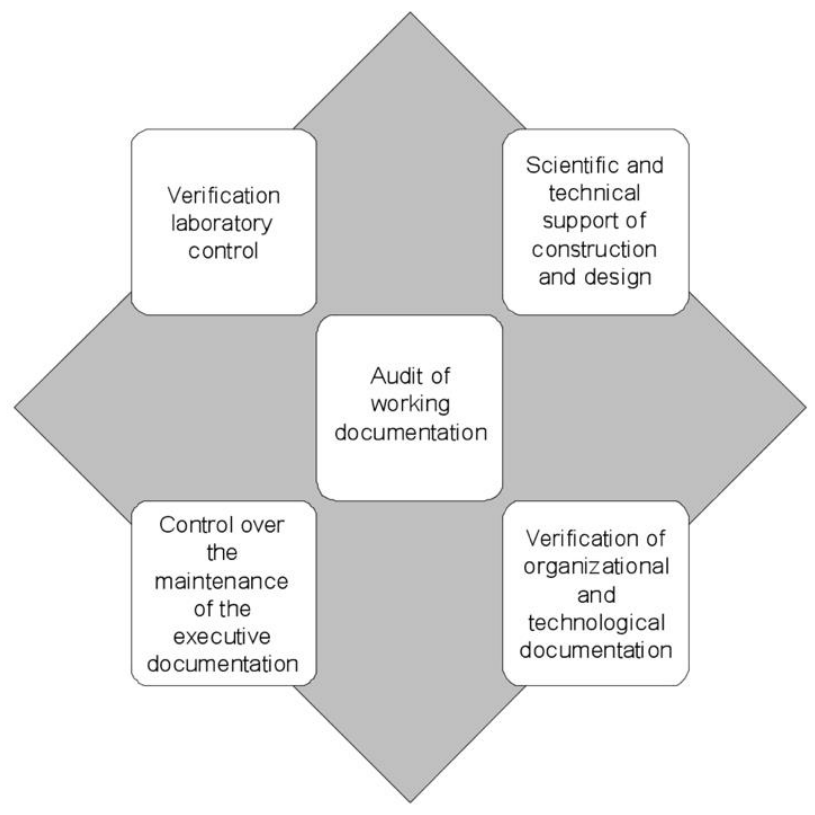

Fig. 3. The integral matrix of construction supervision.

\section{Results}

The result of the study can be considered the following conclusions and suggestions:

1) the situation with the procedure of construction supervision in Russia requires reforms and changes that need to start with an assessment of available resources and the construction of a correct system of relations between participants in construction activities.

2) necessity of specification of structure and volume of the construction supervision for each participant of construction activity. This can be done by adding to regulatory documents:

- general requirements for the composition and scope of construction control;

- Tolerances required for construction supervisors;

3) the need for standardization of verification control by the technical customer, which would include integrated selective control at all stages of production, from design to maintenance of facilities. Moreover, its share can be determined by the following dependence: 


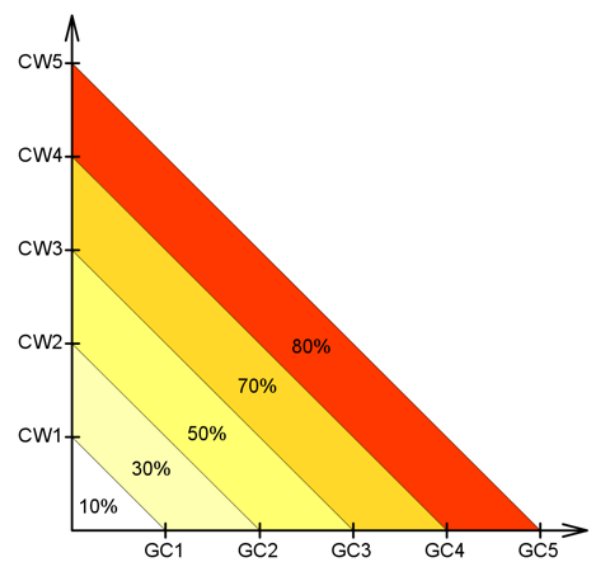

Fig. 4. A conceptual model for determining the capacity of verification products under construction control of a technical customer.

In this model, the following designations are used:

a) CW- category of controlled work:

- CW1- other works;

- $\quad$ CW2- all kinds of auxiliary work;

- $\quad$ CW3 - finishing work;

- CW4- works related to walling;

- CW5- work related to bearing structures;

b) GC is a complex indicator, in gradation from more to less characterizing the readiness of the general contractor to complete the controlling package of work and self-control. The factors of this complex indicator include: the power of the company, the experience and professionalism of the team, the degree of qualification of employees, the presence of its own testing laboratory.

In the absence of baseline data, the proportion of verification control should be on average about $30 \%$ of the total construction control of the general contractor.

$$
\mathrm{V}=0.3 \cdot \text { Stot }
$$

where V-scope of verification control by the customer; Stot - full scope of contractor's contractor control.

4) the proposal to create a single register of specialists, whose participants could make private consultations and independent construction control of all stages of the construction process. Entry into this register must be made on the principles of professional recognition, high qualification and increased degree of individual responsibility.

5) strengthening the work on training. The creation of a single register of specialists will solve only part of the problems. Also an important part of this system should be the possibility of continuing professional development of specialists and their re-certification. To this end, it is necessary to involve specialized higher education institutions in order to solve the problem.

\section{Conclusions}

The proposals expressed in the article are aimed at improving the situation with the control and supervisory function as a whole. These decisions are aimed at eliminating problems that cause a lot of criticism of the quality of construction works, lack of full-scale construction 
control, non-fulfillment of contractual obligations, and overall lag behind world standards of investment development.

\section{References}

1. Urban Development Code of the Russian Federation from 29.12.2004 N 190-FZ (Moscow, 2018)

2. Resolution of the Government of the Russian Federation of June 21, $2010 \mathrm{~N} 468$ (Moscow, 2010)

3. Order of the Ministry of Regional Development of the Russian Federation of 30.12.2009 N 624 (Russia, Moscow, 2004)

4. Order of the State Construction Committee of the Russian Federation of 25.02.1999 N 39 (Moscow, 1999)

5. D. Topchiy, A. Shatrova, A. Yurgaytis, MATEC Web of Conferences 193, 05032 (2018) https://doi.org/10.1051/matecconf/201819305032

6. D. Topchiy, E. Kochurina, MATEC Web of Conferences 193, 05012 (2018) https://doi.org/10.1051/matecconf/201819305012

7. D. Topchiy, A. Tokarskiy, MATEC Web of Conferences 196(1), 04029 https://doi.org/10.1051/matecconf/201819604029

8. E. Vasilyeva, MATEC Web of Conferences 193, 01025 (2018)

9. D.V. Topchiy, A.I. Shatrova, International Journal of Mechanical Engineering and Technology 4(9), 539-547 (2018)

10. A. Mottaeva, MATEC Web of Conferences 106, 08071 (2017)

11. D. Topchiy, A. Tokarskiy, IOP Conference Series: Materials Science and Engineering 365, 1-7 (2018) 